$$
\text { Pontifícia Universidade } \text { Católica }_{\text {do Rio de Janeiro }}
$$

Bruno da Costa Flach

\title{
Stochastic Programming with Endogenous Uncertainty: An Application in Humanitarian Logistics
}

\section{Tese de Doutorado}

Thesis presented to the Postgraduate Program in Engenharia Elétrica of the Departamento de Engenharia Elétrica, PUC-Rio in partial fulfillment of the requirements for the degree of Doutor em Engenharia Elétrica.

Advisor: $\quad$ Prof. Álvaro de Lima Veiga Filho

Co-Advisor: Prof. Marcus Vinicius Soledade Poggi de Aragão

Rio de Janeiro

April, 2010 


$$
\text { Pontifícia Universidade } \text { C }_{\text {atólica }} \text { do Rio de Janeiro }
$$

Bruno da Costa Flach

\title{
Stochastic Programming with Endogenous Uncertainty: An Application in Humanitarian Logistics
}

Thesis presented to the Postgraduate Program in Engenharia Elétrica of the Departamento de Engenharia Elétrica, PUC-Rio in partial fulfillment of the requirements for the degree of Doutor em Engenharia Elétrica. Approved by the following commission:

\author{
Prof. Álvaro de Lima Veiga Filho \\ Advisor \\ Departamento de Engenharia Elétrica - PUC-Rio \\ Prof. Marcus Vinicius Soledade Poggi de Aragão \\ Co-Advisor \\ Departamento de Informática - PUC-Rio \\ Prof. Eduardo Uchoa Barboza \\ Departamento de Engenharia de Produção - UFF \\ Prof. Geraldo Veiga \\ Rn Ciência e Tecnologia \\ Prof. Alexandre Street de Aguiar \\ Departamento de Engenharia Elétrica - PUC-Rio \\ Prof. Oscar Porto \\ Gapso \\ Prof. José Eugenio Leal \\ Coordenador Setorial do Centro Técnico Científico
}

Rio de Janeiro - April $16^{\text {th }}, 2010$ 
All rights reserved.

\section{Bruno da Costa Flach}

Bruno Flach graduated in Industrial Engineering and Electrical Engineering with emphasis on Telecommunications in 2002. In 2004, he obtained an MSc degree in Electrical Engineering within the Operations Research Group. During the $\mathrm{PhD}$, he was a visiting researcher at CARISMA (Centre for the Analysis of Risk and Optimisation Modelling Applications) at the Mathematical Sciences Department of Brunel University, UK.

Bibliographic data

Flach, Bruno da Costa

Stochastic Programming with Endogenous Uncertainty: An Application in Humanitarian Logistics / Bruno da Costa Flach; orientador: Álvaro de Lima Veiga Filho; coorientador: Marcus Vinicius Soledade Poggi de Aragão. 2010.

74 f. ; $30 \mathrm{~cm}$

Tese (Doutorado) - Pontifícia Universidade Católica do Rio de Janeiro, Departamento de Engenharia Elétrica, 2010.

Inclui bibliografia

1. Engenharia Elétrica - Teses. 2. Otimização estocástica. 3. Incertezas Endógenas. 4. Convexificação. 5. Logística humanitária. I. Veiga Filho, Álvaro de Lima. II. Aragão, Marcus Vinicius Soledade Poggi de. III. Pontifícia Universidade Católica do Rio de Janeiro. Departamento de Engenharia Elétrica. IV. Título. 


\section{Acknowledgments}

To God, for the opportunity to live and experience His universe.

Ao amor de todas as minhas vidas Lavinia (a.k.a. Nines), com quem compartilho a alma. Pelo amor que me infla o espírito e por me lembrar todos os dias o que realmente importa na vida.

Aos meus pais Otto e Lânia, pelo amor, dedicação, entusiasmo e exemplos de fé, força e coragem que fazem parte de mim e compõem quem eu sou.

A minha irmã Luciana, pelo amor, carinho, amizade, alegria e pelo exemplo de tantas qualidades que eu tentarei adquirir ao longo da vida.

A toda minha família, pelo amor, força, fé e incentivo que eu carrego em todos os momentos da vida.

To my friend and advisor Marcus Poggi, for all the opportunities and motivation throughout my academic and professional life.

To my advisor Álvaro Veiga, for all the teachings and always pleasant conversations, related or not to this thesis.

To Professor Gautam Mitra and all friends at Brunel University, for the opportunity and amazing work environment where this thesis was born.

To my great friends Alexandre Street and Eduardo Faria, with whom I have shared the path from college to the $\mathrm{PhD}$.

To all my friends, for support, help and all the fun we have had.

To CNPq and PUC-Rio, for the financial support and excellent work environment. 


\section{Abstract}

Flach, Bruno da Costa; Veiga Filho, Álvaro de Lima (Advisor); Aragão, Marcus Vinicius Soledad Poggi de (Co-Advisor). Stochastic Programming Models with Endogenous Uncertainty: An Application in Humanitarian Logistics. Rio de Janeiro, 2010. 74 p. PhD Thesis - Electrical Engineering Department, Pontifical Catholic University, Rio de Janeiro (PUC-Rio).

In this work we study a class of stochastic programming problems with endogenous uncertainty - i.e., those in which the probability distribution of the random parameters is decision-dependent - which is formulated as a mixed integer non-linear programming (MINLP) problem. Although discussed in the context of the humanitarian logistics problem, the proposed methodology and obtained results are also valid for a more general class of problems which comprehends a variety of applications. In particular, we propose (i) a convexification technique for polynomials of binary variables, (ii) an efficient cutgeneration algorithm and (iii) the incorporation of importance sampling concepts into the stochastic programming framework so as to allow the solution of large instances of the problem. Computational results demonstrate the effectiveness of the proposed methodology by solving instances significantly larger than those reported in related works.

\section{Keywords}

Stochastic programming; Endogenous uncertainty; Convexification; Importance sampling; Humanitarian logistics. 


\section{Resumo}

Flach, Bruno da Costa; Veiga Filho, Álvaro de Lima (Orientador); Poggi de Aragão, Marcus Vinicius Soledad (Co-Orientador). Modelos de Programação Estocástica com Incertezas Endógenas: Uma Aplicação em Logística Humanitária. Rio de Janeiro, 2010. 74 f. Tese de Doutorado - Departamento de Engenharia Elétrica, Pontifícia Universidade Católica do Rio de Janeiro.

Neste trabalho estudamos uma classe de problemas de otimização estocástica com incertezas endógenas que é formulado como um problema de programação não-linear inteira (MINLP). Esta classe de problemas difere dos problemas de otimização estocástica geralmente estudados na literatura pelo fato de que que a distribuição de probabilidade dos parâmetros aleatórios depende das decisões tomadas. Apesar de discutido dentro do contexto do problema de logística humanitária, a metodologia proposta e os resutados obtidos são válidos para uma classe geral de problemas que agrega uma variedade de aplicações. Em particular, propõe-se (i) uma técnica de convexificação de polinômios de variáveis binárias, (ii) um algoritmo de geração de cortes e (iii) a incorporação dos conceitos de importance sampling dentro do contexto de otimização estocástica de modo a permitir a solução de grandes instâncias do problema. Os resultados computacionais apresentados demonstram as vantagens da metodologia proposta ao permitir a solução de instâncias significativamente maiores que aquelas atualmente apresentadas em trabalhos relacionados.

\section{Palavras-chave}

Otimização estocástica; Incertezas endógenas; Convexificação; Logística Humanitária. 


\section{Contents}

1 INTRODUCTION 12

1.1 Decision under uncertainty 12

1.2 Robust Optimization 12

$\begin{array}{lll}1.3 & \text { Stochastic programming } & 15\end{array}$

$\begin{array}{lll}1.4 & \text { Motivation and related bibliography } & 17\end{array}$

1.5 Objective and contributions 21

1.6 Outline 22

2 HUMANITARIAN LOGISTICS PROBLEM 24

2.1 Introduction 24

2.2 Literature review 25

$\begin{array}{lll}2.3 & \text { Mathematical formulation } & 27\end{array}$

3 REFORMULATION SCHEME 30

3.1 Separability of second stage problems 30

3.2 Polynomials in binary variables 31

$\begin{array}{lll}3.3 & \text { Approximation } & 37\end{array}$

4 CUT GENERATION ALGORITHM 44

4.1 Active cuts at the optimal solution 44

4.2 Solution properties 44

4.3 Approximation of the second-stage cost function 45

4.4 An algorithm considering the gap to the global optimal solution 47

5 SCENARIO GENERATION 49

$\begin{array}{ll}5.1 \text { Difficulty in scenario generation } & 49\end{array}$

5.2 Importance sampling 49

$\begin{array}{lll}5.3 & \text { Reformulation } & 50\end{array}$

5.4 Solution robustness 52 
6 COMPUTATIONAL RESULTS 53

6.1 Instances from the literature 53

6.2 Medium-size instances $\quad 57$

$\begin{array}{lll}6.3 & \text { Large-size instances } & 60\end{array}$

7 CONCLUSIONS 63

$\begin{array}{lll}7.1 & \text { Future work and extensions } & 63\end{array}$

APPENDIX A: Generalization with respect to second-stage problems 65

A.1 Problems solved with full scenario enumeration 65

A.2 Problems solved with a sample of scenarios 66

$\begin{array}{ll}\text { APPENDIX B: Solution robustness } & 67\end{array}$

$\begin{array}{ll}\text { REFERENCES } & 69\end{array}$ 


\section{List of Figures}

Figure 1-1 - Two-stage (A) and multistage (B) scenario-tree structure of stochastic programming models

Figure 1-2 - Stochastic programming model with exogenous uncertainty - probabilities $\boldsymbol{p 1}, \boldsymbol{p 2}, \boldsymbol{p 3}$ and $\boldsymbol{p 4}$ are independent of decision $\boldsymbol{x}$ 18

Figure 1-3 - Endogenous uncertainty related to the time of information discovery

Figure 1-4 - Endogenous uncertainty and decision-dependent

probabilities 20

Figure 3-1 - Two-link network example 33

Figure 3-2 - Inequalities that provide a piecewise linear approximation to the exponential function 34

Figure 3-3 - Piecewise linear approximation of the exponential function. 36

Figure 3-4 - Linear approximation to the exponential function provided by a cut centered on $\ln (45 \%)$

Figure 3-5 - Percentage error provided by a linear approximation centered on $\ln (45 \%)$ and illustration of $\boldsymbol{\eta}+$ and $\boldsymbol{\eta}-$ for $\boldsymbol{\varepsilon}=\mathbf{1 0} \%$

Figure 6-1 - Graph corresponding to the instances solved in

Viswanath et al. [66] 54

Figure 6-2 - Algorithm perfomance on an 15-edge instance with full scenario enumeration. 60 


\section{List of Tables}

Table 3-1 - Probability of occurrence of scenario $\boldsymbol{s} \mathbf{1}$ according to the

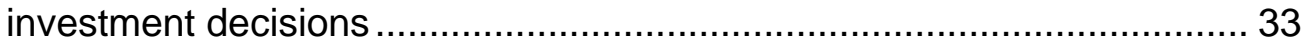

Table 6-1 - Description of the instances provided in

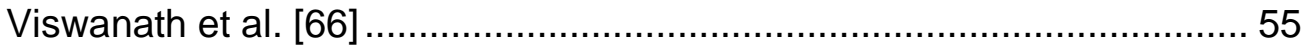

Table 6-2 - Results of the instances provided in Viswanath et al. [66] ... 56

Table 6-3 - Results for the medium-size instances .............................. 58

Table 6-4 - Results for the medium-size instances .............................. 59

Table $6-5$ - Results for the large-size instances................................ 62 